\title{
Front Matter: Volume 10389
}

, "Front Matter: Volume 10389," Proc. SPIE 10389, X-Ray Nanoimaging: Instruments and Methods III, 1038901 (25 October 2017); doi: 10.1117/12.2296011

SPIE Event: SPIE Optical Engineering + Applications, 2017, San Diego, California, SPIE. United States 


\section{PROCEEDINGS OF SPIE}

\section{$X$-Ray Nanoimaging: Instruments and Methods III}

Barry Lai

Andrea Somogyi

Editors

7-8 August 2017

San Diego, California, United States

Sponsored by

SPIE

Cosponsored by

XIA LLC (United States)

Published by

SPIE 
The papers in this volume were part of the technical conference cited on the cover and title page. Papers were selected and subject to review by the editors and conference program committee. Some conference presentations may not be available for publication. Additional papers and presentation recordings may be available online in the SPIE Digital Library at SPIEDigitalLibrary.org.

The papers reflect the work and thoughts of the authors and are published herein as submitted. The publisher is not responsible for the validity of the information or for any outcomes resulting from reliance thereon.

Please use the following format to cite material from these proceedings:

Author(s), "Title of Paper," in X-Ray Nanoimaging: Instruments and Methods III, edited by Barry Lai, Andrea Somogyi, Proceedings of SPIE Vol. 10389 (SPIE, Bellingham, WA, 2017) Seven-digit Article CID Number.

ISSN: 0277-786X

ISSN: 1996-756X (electronic)

ISBN: 9781510612358

ISBN: 9781510612365 (electronic)

Published by

SPIE

P.O. Box 10, Bellingham, Washington $98227-0010$ USA

Telephone +1 3606763290 (Pacific Time) · Fax +1 3606471445

SPIE.org

Copyright (C) 2017, Society of Photo-Optical Instrumentation Engineers.

Copying of material in this book for internal or personal use, or for the internal or personal use of specific clients, beyond the fair use provisions granted by the U.S. Copyright Law is authorized by SPIE subject to payment of copying fees. The Transactional Reporting Service base fee for this volume is $\$ 18.00$ per article (or portion thereof), which should be paid directly to the Copyright Clearance Center (CCC), 222 Rosewood Drive, Danvers, MA 01923. Payment may also be made electronically through CCC Online at copyright.com. Other copying for republication, resale, advertising or promotion, or any form of systematic or multiple reproduction of any material in this book is prohibited except with permission in writing from the publisher. The CCC fee code is 0277$786 \mathrm{X} / 17 / \$ 18.00$.

Printed in the United States of America.

Publication of record for individual papers is online in the SPIE Digital Library.

\section{SPIE. DIGITAL}

Paper Numbering: Proceedings of SPIE follow an e-First publication model. A unique citation identifier (CID) number is assigned to each article at the time of publication. Utilization of CIDs allows articles to be fully citable as soon as they are published online, and connects the same identifier to all online and print versions of the publication. SPIE uses a seven-digit CID article numbering system structured as follows:

- The first five digits correspond to the SPIE volume number.

- The last two digits indicate publication order within the volume using a Base 36 numbering system employing both numerals and letters. These two-number sets start with $00,01,02,03$, 04, 05, 06, 07, 08, 09, 0A, OB ... 0Z, followed by 10-1Z, 20-2Z, etc. The CID Number appears on each page of the manuscript. 


\title{
Contents
}

\author{
$\checkmark$ Authors \\ vii Conference Committee
}

OPTICS

1038909 Focus of a multilayer Lave lens with an aperture of 102 microns determined by ptychography at beamline 1-BM at the Advanced Photon Source [10389-8]

\section{NANO-IMAGING/CORRELATIVE METHODS}

10389 OD Simulations and experiments on vibration damping for zoom-holography and nanoscanning at the GINIX [10389-12]

10389 OE PtyNAMi: ptychographic nano-analytical microscope at PETRA III: interferometrically tracking positions for 3D x-ray scanning microscopy using a ball-lens retroreflector [10389-13]

10389 OF High-energy cryo x-ray nano-imaging at the ID16A beamline of ESRF (Invited Paper) [10389-14]

\section{SCANNING NANOPROBES}

10389 0J Current status of the hard X-ray nanoprobe beamline at the SSRF (Invited Paper) [10389-19]

10389 OK First $x$-ray nanoimaging experiments at NanoMAX [10389-20]

\section{POSTER SESSION}

10389 OT Faster scanning and higher resolution: new setup for multilayer zone plate imaging [10389-29]

10389 OU PYXRF: Python-based x-ray fluorescence analysis package [10389-30]

1038914 Arsenic distribution and valence state variation studied by fast hierarchical length-scale morphological, compositional, and speciation imaging at the Nanoscopium, Synchrotron Soleil [10389-41] 
Proc. of SPIE Vol. 10389 1038901-4

Downloaded From: https://www.spiedigitallibrary.org/conference-proceedings-of-spie on 26 Apr 2023 Terms of Use: https://www.spiedigitallibrary.org/terms-of-use 


\section{Authors}

Numbers in the index correspond to the last two digits of the seven-digit citation identifier (CID) article numbering system used in Proceedings of SPIE. The first five digits reflect the volume number. Base 36 numbering is employed for the last two digits and indicates the order of articles within the volume. Numbers start with 00, 01, 02, 03, 04, 05, 06, 07, 08, 09, 0A, 0B...0Z, followed by 10-1Z, 20-2Z, etc.

Baranton, Gil, 14

Björling, Alexander, OK

Bloch, Leonid, OF

Bohic, Sylvain, OF

Botta, Stephan, OE

Bouet, Nathalie, 09

Campbell, Stuart I., OU

Carbone, Gerardina, OK

Chu, Yong S., OU

Cloetens, Peter, OF

Conley, Raymond, 09

da Silva, Julio C., OF

Döhrmann, Ralph, OE

Eberl, Christian, OT

Falkenberg, Gerald, OE

Fus, Florin, OF

Garrevoet, Jan, $0 \mathrm{E}$

$\mathrm{He}$, Yan, OJ

Heroux, Annie, OU

Hubert, Maxime, OF

Jiang, Hui, OJ

Johansson, UIf, OK

Kahnt, Maik, OE

Kalbfleisch, Sebastian, OK

Krebs, Hans-Ulrich, OT

Lee, Wah-Keat, OU

Li, Aiguo, OJ

$\mathrm{Li}, \mathrm{Li}, \mathrm{OU}$

Liebi, Marianne, OK

Luley, Peter, OD

Lyubomirskiy, Mikhail, OE

Macrander, Albert, 09

Maser, Jörg, 09

Matej, Zdenek, OK

Medjoubi, Kadda, 14

Mikkelsen, Anders, OK

Osterhoff, Markus, OD, OT

Pacureanu, Alexandra, OF

Parfeniukas, Karolis, OK

Philippot, Pascal, 14

Salditt, Tim, OD

Salome, Murielle, OF

Sancho-Tomas, Maria, 14

Scholz, Maria, OE

Schroer, Christian G., OE

Schropp, Andreas, OE

Seyrich, Martin, OE

Shu, Deming, OJ

Soltau, Jakob, OT
Somogyi, Andrea, 14

Sprung, Michael, OD

Stankevič, Tomaš, OK

Visscher, P. T., 14

Vogt, Ulrich, OK

Wang, Hua, OJ

Wittwer, Felix, OE

Wojcik, Michael, 09

$\mathrm{XU}, \mathrm{Wei}, \mathrm{OU}$

Yan, Hanfei, OU

Yang, Yang, OF

Yu, Dantong, OU

Zhang, Zhaohong, $0 \mathrm{~J}$

Zhao, Gaofeng, OJ 
Proc. of SPIE Vol. 10389 1038901-6

Downloaded From: https://www.spiedigitallibrary.org/conference-proceedings-of-spie on 26 Apr 2023 Terms of Use: https://www.spiedigitallibrary.org/terms-of-use 


\title{
Conference Committee
}

\author{
Conference Chairs
}

Barry Lai, Argonne National Laboratory (United States)

Andrea Somogyi, Synchrotron SOLEIL (France)

Program Track Chairs

Ali M. Khounsary, Illinois Institute of Technology (United States)

Ralph B. James, Savannah River National Laboratory (United States)

Conference Program Committee

Yong S. Chu, Brookhaven National Laboratory (United States)

Michael Feser, Lyncean Technologies, Inc. (United States)

Hans M. Hertz, Royal Institute of Technology (Sweden)

Ian McNulty, Argonne National Laboratory (United States)

David Paterson, Australian Synchrotron (Australia)

Christian G. Schroer, DESY, University of Hamburg (Germany)

Kazuto Yamauchi, Osaka University (Japan)

Session Chairs

1 Full-Field Imaging

Hans M. Hertz, KTH Royal Institute of Technology (Sweden)

2 Optics

Christian G. Schroer, Deutsches Elektronen-Synchrotron (Germany)

3 Nano-Imaging/Correlative Methods

Stefan Vogt, Argonne National Laboratory (United States)

4 Control Schemes, Data Analysis, Image Reconstruction, and Modeling

Stefan Vogt, Argonne National Laboratory (United States)

5 Scanning Nanoprobes

Andrea Somogyi, Synchrotron SOLEIL (France)

6 Instruments for Nanoimaging and Nanopositioning

Barry Lai, Argonne National Laboratory (United States) 
Proc. of SPIE Vol. 10389 1038901-8

Downloaded From: https://www.spiedigitallibrary.org/conference-proceedings-of-spie on 26 Apr 2023 Terms of Use: https://www.spiedigitallibrary.org/terms-of-use 